\title{
Additional files
}

\section{A novel nanoprobe based on core-shell Au@Pt@mesoporous $\mathrm{SiO}_{2}$ nanozyme with enhanced activity and stability for mumps virus diagnosis}

Lin Long ${ }^{1,2 \dagger}$, Rui Cai ${ }^{3,4 \dagger}$, Jianbo Liu ${ }^{1^{*}}$ and Xiaochun $\mathrm{Wu}^{3,4^{*}}$

${ }^{1}$ College of Opto-electronic Engineering, Zaozhuang University, Zaozhuang, China

${ }^{2}$ Zaozhuang Municipal Center for Disease Control and Prevention, Zaozhuang, China

${ }^{3}$ CAS Key Laboratory of Standardization and Measurement for Nanotechnology,

National Center for Nanoscience and Technology, Beijing, China

${ }^{4}$ University of Chinese Academy of Sciences, Beijing, China

${ }^{\prime}$ These authors contributed equally to this work

*Corresponding author email: linyibm@163.com (J.Liu),wuxc@nanoctr.cn (X.Wu)) 


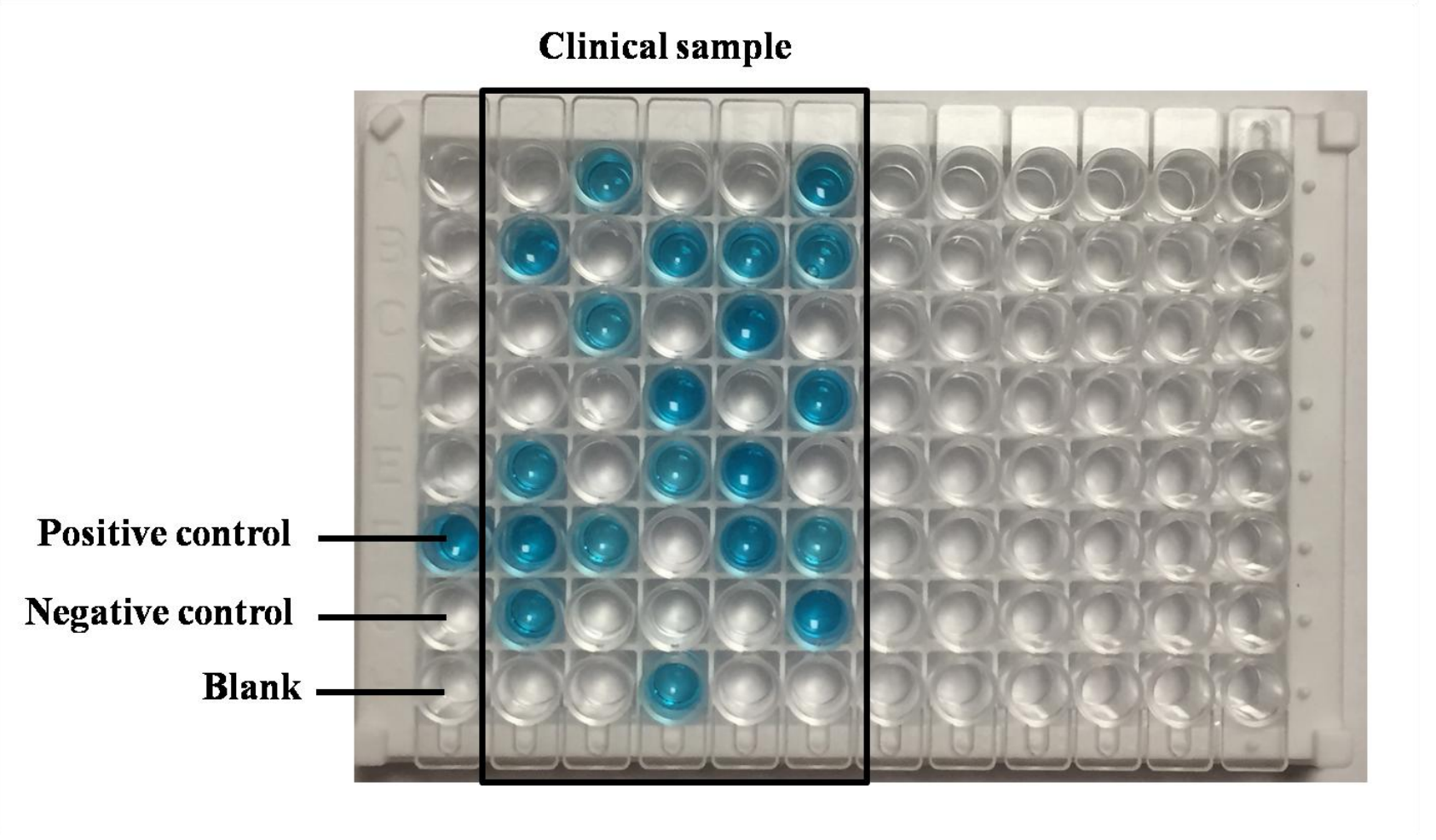

Figure S1 Colorimetric ELISA detection of mumps IgM in the clinical serum with Ags-APMSN-based ELISA 
Table S1 Detection of mumps IgM in the clinical serum obtained by the Ags-APMSN-based ELISA.

\begin{tabular}{|c|c|c|}
\hline Sample & OD650 & Result (Positive / Negative) \\
\hline 1 & 1.119 & Positive \\
\hline 2 & 1.084 & Positive \\
\hline 3 & 0.894 & Positive \\
\hline 4 & 1.09 & Positive \\
\hline 5 & 0.936 & Positive \\
\hline 6 & 1.129 & Positive \\
\hline 7 & 0.961 & Positive \\
\hline 8 & 1.113 & Positive \\
\hline 9 & 1.108 & Positive \\
\hline 10 & 0.978 & Positive \\
\hline 11 & 0.985 & Positive \\
\hline 12 & 0.996 & Positive \\
\hline 13 & 1.207 & Positive \\
\hline 14 & 0.936 & Positive \\
\hline 15 & 1.012 & Positive \\
\hline 16 & 1.121 & Positive \\
\hline 17 & 0.986 & Positive \\
\hline 18 & 0.968 & Positive \\
\hline 19 & 0.913 & Positive \\
\hline 20 & 0.952 & Positive \\
\hline 21 & 0.102 & Negative \\
\hline 22 & 0.173 & Negative \\
\hline 23 & 0.142 & Negative \\
\hline 24 & 0.165 & Negative \\
\hline 25 & 0.103 & Negative \\
\hline 26 & 0.144 & Negative \\
\hline 27 & 0.122 & Negative \\
\hline 28 & 0.134 & Negative \\
\hline 29 & 0.152 & Negative \\
\hline 30 & 0.173 & Negative \\
\hline 31 & 0.145 & Negative \\
\hline 32 & 0.137 & Negative \\
\hline 33 & 0.125 & Negative \\
\hline 34 & 0.132 & Negative \\
\hline 35 & 0.165 & Negative \\
\hline 36 & 0.0987 & Negative \\
\hline 37 & 0.123 & Negative \\
\hline 38 & 0.0846 & Negative \\
\hline 39 & 0.173 & Negative \\
\hline 40 & 0.104 & Negative \\
\hline
\end{tabular}

